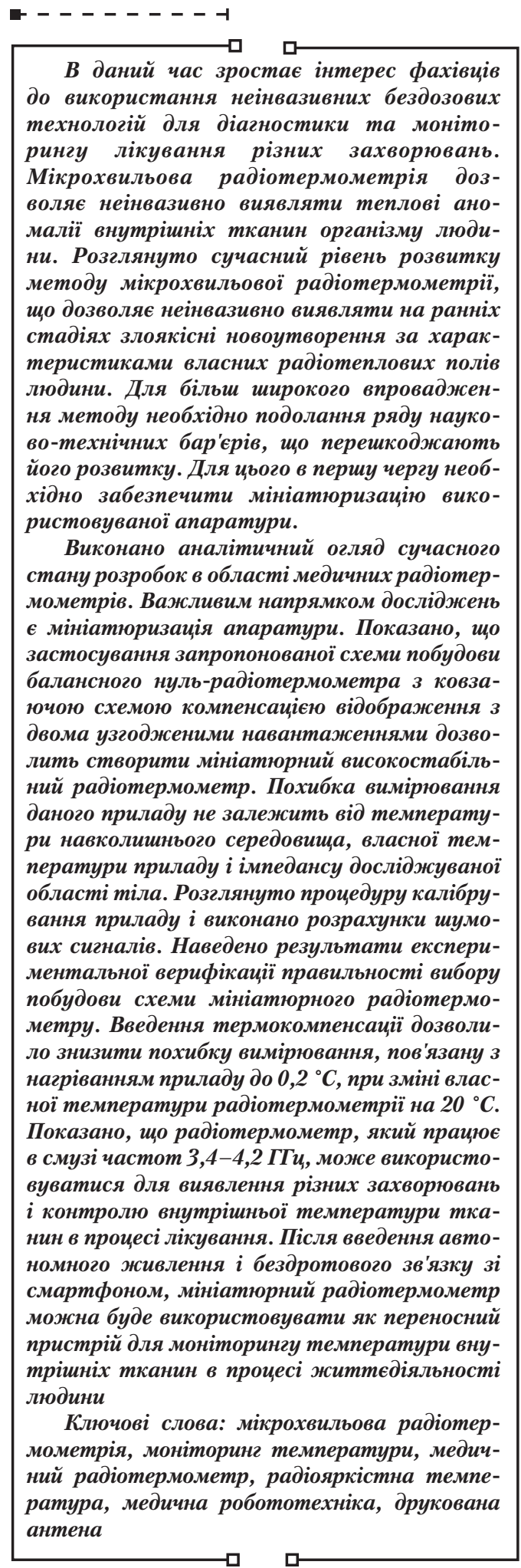

В даний час зростає інтерес фахівчі до використання неінвазивних бездозових технологій для діагностики та монітоМікрохвильова радіотермометрія дозволяє неінвазивно виявляти теплові анометоду мікрохвильової радіотермометріі, що дозволяє неінвазивно виявляти на ранніх о алія злоякісні новоутворення за хараклюдини. Для більм широкого впровадження методу необхідно подолання ряду науково-технічних бар'єрів, що перешкоджають його розвитку. Для цього в периу иергу необ-

Виконано аналітичний огляд сучасного ючою схемою компенсачією відображення двома узгодженими навантаженнями дозводаного приладу не залежсть від температу ри навколишнього середовища, власної температури приладу і імпедансу досліджувано області тіла. Розглянуто процедуру калібру вання приладу і виконано розрахунки шумоментальної верифікачї правильності вибору побудови схеми мініатюрного радіотермометру. Введення термокомпенсачії дозволинагріванням приладу $0002^{\circ} \mathrm{C}$ при зміні влас ної температури радіотермометрії на $20{ }^{\circ} \mathrm{C}$ Показано, що радіотермометр, який працюе смартфоном, мініатюорний радіотермометр можна буде використовувати як переноснии

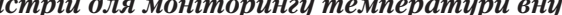
юодини ний радіотермометр, радіояркістна темпе антена

Received date 10.06.2019

Accepted date 04.08.2019

Published date 28.08.2019
UDC 182.536

DOI: $10.15587 / 1729-4061.2019 .176357$

\section{RESEARCH OF A MICROWAVE RADIOMETER FOR MONITORING OF INTERNAL TEMPERATURE OF BIOLOGICAL TISSUES}

S. Ves n i n

$\mathrm{PhD}$, Chief Designer

Technical Department

LLC "RTM Diagnostics"

Bol'shaya Pochtovaya str., 55/59, Moscow, Russian Federation, 105082

$\mathrm{PhD}$, Senior Researcher*

Bauman Moscow State Technical University 2nd Baumanskaya str., 5, Moscow, Russian Federation, 105005

M. S e d a n k i n

$\mathrm{PhD}$, Senior Researcher

Department of Radiation Epidemiology

State Research Center - Burnasyan Federal Medical Biophysical Center of Federal Medical Biological Agency

Marshala Novikova str., 23, Moscow, Russian Federation, 123098

E-mail: msedankin@yandex.ru

L. Ov c hin n i k ov

Business Development Section Staff

Okinawa Institute Of Science And Technology

1919-1 Tancha, Onna-son, Kunigami-gun, Okinawa-ken, Japan

V. Le us h i n

$\mathrm{PhD}$, Senior Researcher*

V. Skuratov

Engineer, Researcher

Department of Antennas and Microwave Devices

All-Russian Research Institute of Radio Engineering

Bol'shaya Pochtovaya str., 22, Moscow, Russian Federation, 105082

I. Neli n

$\mathrm{PhD}$, Associate Professor

Department of Radiolocation, Radio Navigation and On-Board Radio

Electronic Equipment

Moscow Aviation Institute

Volokolamskoe highway, 4, Moscow, Russian Federation, 125993

A. Konovalova

Department of Bio-Cybernetic Systems and Technologies Russian Technological University

Vernadskogo ave., 78, Moscow, Russian Federation, 119454

*Bauman Moscow State Technical University 2nd Baumanskaya str., 5, Moscow, Russian Federation, 105005

\section{Introduction}

Currently, there is a growing interest among specialists to the use of non-invasive no-dose methods for diagnosis and monitoring of treatment of various diseases. Such methods, in particular, include the method of microwave radiometry (MWR) which makes it possible to measure tissue self-radiation in a microwave range and visualize temperature of 
internal human tissues based on these data. Unlike infrared thermography which measures skin temperature, MWR enables obtaining of information about thermal abnormalities at a depth of 3-7 cm depending on moisture content in the tissue and the frequency range used. In recent years, many new publications on the use of MWR in medicine have appeared. MWR is used in mammalogy to detect breast cancer and monitor progress of treatment of various diseases of the mammary glands $[1,2]$. The method is used in critical care medicine to measure brain temperature during treatment of cerebral stroke and traumas [3]. A series of studies related to identification of inflamed atherosclerotic plaques and assessment of stroke risk have been carried out [4,5]. MWR is also used in non-invasive diagnosis of arthritis [6], brown fat activity [7] and examinations of brain [8, 9], spine [10] and joints [11]. Interesting results were obtained in the field of phlebology [12], experimental oncology [13], gynecology [14] and urology $[15,16]$. Besides, MWR was also used to study microwave radiation of enzymes [17, 18]. The scope of MWR is expanding every day but, at the same time, there are a series of scientific and technological barriers that must be overcome for further development of this method. Further development is limited to the use of stationary, single-channel devices. During examination, doctor measures internal temperature in various points of the organ being examined. Usually temperature is measured at $18-20$ points during examination. However, there are obviously a large number of medical problems when it is necessary to monitor temperature of internal tissues. For example, it can be monitoring during hypothermia and hyperthermia or temperature monitoring under influence of various loads and functional tests. Single-channel radiometers are only the first step in the development of MWR. The future belongs to multichannel devices that ensure simultaneous measurements in several points and visualize temperature of the organ under study in real time. First of all, this problem is relevant for monitoring internal temperature under various influences. But to create multichannel devices, it is necessary to radically reduce dimensions of the microwave radiometer since the single-channel devices used currently weigh up to $4.5 \mathrm{~kg}$ [19]. Therefore, mechanical channel number growth is impossible and it is necessary to use new circuits for designing microwave radiometers capable of reducing their dimensions by an order of magnitude. Obviously, the use of monolithic microwave integrated circuits (MMIC) and implementation of microwave devices using HEMT and MIS technologies described in detail in [20-27] can significantly reduce device dimensions and improve its reliability. In addition, specialists have recently increased interest in miniature, wearable temperature measuring devices that can be used in everyday human life. It is impossible to use conventional scheme for designing a microwave radiometers for these purposes, so other approaches should be considered.

\section{Literature review and problem statement}

Most of the mentioned studies used a scheme of a single-channel microwave radiometer described in [19]. To date, more than 60 thousand patients in a number of countries have been examined with the help of this device. It is a single-frequency radiometer operating in the range of 3.4-4.2 GHz. It features measurement of self-radiation in microwave and infrared ranges which enables simultaneous measurement of both internal tissue temperature and skin temperature. The device consists of a two-frequency sensor held in the doctor's hand and a data processing unit with dimensions of $30 \times 40 \times 20 \mathrm{~cm}$. It is a null balance radiometer with a sliding circuit of reflection compensation which provides high accuracy of measuring internal temperature. However, the device has rather large dimensions and it is impossible to use its scheme to build a miniature radiometer. Besides a single-channel radiometer [19], a series of other microwave radiometers are known. They are described below.

An original microwave radiometer was described in [26]. Unlike the conventional Dicke radiometer, it measures not only temperature of internal tissues but also allows one to measure of antenna reflection coefficient and thus compensate for existing antenna reflections. As compared with a radiometer, block diagram of this device has some special features [19]. This device also represents a stationary radiometer. It is impractical to use technical solutions incorporated in it to design a miniature radiometer.

In recent years, several studies that discuss issues of designing miniature microwave radiometers have been published.

A single-channel microwave radiometer operating at a frequency of $1.35 \mathrm{GHz}$ with a transmission bandwidth of $500 \mathrm{MHz}$ was used in [29] to monitor temperature of internal tissues. Reception of self radiation in the decimeter range opens up the possibility of detecting thermal abnormalities at a relatively large depth of up to $50-70 \mathrm{~mm}$. A modified total power radiometer with two reference noise sources was used as a radio thermometer. The device consists of two blocks. The first block includes a switch, two reference noise sources and the first stage of a low-noise amplifier with gain factor of $10-15 \mathrm{~dB}$. This part of the radiometer is incorporated in the antenna and connected to the second unit via a coaxial cable. Microwave signal amplification, filtering, detection and analog-to-digital conversion are performed in the second block. The signal is further processed in a laptop. The radiometer communicates with the laptop through a USB interface. This is a rather compact radiometer which could potentially be used to monitor temperature of internal tissues in everyday human life.

Interesting results of development of miniature wearable radiometers are presented in [30,31]. A compact microwave radiometer operating in a frequency range of $1.4-1.427 \mathrm{GHz}$ was described in [30,31]. Like that described in [29], it enables detection of thermal anomalies at large depths. To increase noise immunity of the device, the authors have narrowed its bandwidth to $27 \mathrm{MHz}$. Structure of this radiometer is close to that of the device from [29] and includes two reference noise sources, an electronic switch, a two-stage low-noise amplifier (LNA), two bandpass filters (BPF), a sensitive amplitude detector and an analog-to-digital converter (ADC). Implementation of a wireless wearable multi-frequency radiometer was considered in [32]. It features operation in several frequencies which enables temperature measurement at different depths. The radiometer can be implemented in a monolithic design. The authors are planning to use this device for early detection of malignant tumors, monitoring drug delivery for cancer treatment, monitoring temperature during organ transplantation, circadian cycle and in other applications. This radiometer can be implemented in a monolithic design.

The device described in [30-33] are based on a total-power radiometer and do not contain nonreciprocal 
elements. So far, there are few experimental data in scientific literature demonstrating how measurement results of such devices change with a change of impedance of the biological object (BO) under study. Impedance changes occur when antenna is moved from one measuring point to another or when contact between the antenna and the $\mathrm{BO}$ is practically broken. Conventional radiometers without nonreciprocal elements err considerably when input impedance of the object under study changes. Such devices can be used to clarify nature of changes in temperature of internal tissues over time after preliminary calibration of the device in the location under study. Since values of the tissue impedance in different parts of the body differ significantly, the brightness temperature measured in different parts of the body will also differ significantly. This fact can cause difficulties in practical use of the device if special calibration in each point is not done. Therefore, in order to ensure independence of the measurement results from dielectric permeability of the tissue under study, it is desirable to use a null balance radiometer with a reflection compensation scheme.

A miniature single-channel radiometer with a printed antenna for reception of microwave radiation from brain in the $3.6 \mathrm{GHz}$ band with a frequency band of $\mathrm{MHz}$ was presented in [34]. The instrument uses a null balance radiometer with a negative feedback loop. RF load mounted on a Peltier element is used as a source of noise signals. The radiometer has relatively small dimensions: $76 \times 54 \times 22 \mathrm{~mm}$. This work is the first step towards miniaturization of microwave radiometers with nonreciprocal elements. The issues of development of a microwave antenna are discussed in sufficient detail while the issues of creation of a miniature radiometer were not addressed.

Results of modeling a microwave radiometer intended for diagnosis of mammary gland diseases are presented in [35]. Like the radiometer of [19], this device is single-channel. During measurement, doctor holds the sensor in his hand and puts antenna to various points on the mammary gland. Self-radiation is measured simultaneously in five frequency ranges. This makes it possible to determine nature of temperature changes in depth. This radiometer uses a broadband antenna that receives its self-radiation in the frequency range from 1 to $4 \mathrm{GHz}$. All component parts of the radiometer are placed in the sensor connected to the computer via a USB interface. This is a very promising solution, so the authors plan to move on to creating a prototype of the product at the next stage.

Thus, based on the analysis of published data, we can conclude that despite the successful development of MWR, the problem of creating a miniature radiometer has not yet been solved. Most of the described devices have significant dimensions and are suitable only for use in stationary conditions. The known miniature devices have a significant measurement error when the BO impedance changes. Based on the analysis of information sources on the current state of development in the field of medical radiometer, it can be stated that there are a series of scientific and technological barriers that must be overcome for further development of the method. It is also impossible to integrate these devices with other medical devices developed according to the principles of wearable technology.

Creation of a block diagram of a miniature radiometer that can radically reduce overall dimensions and weight of the device can be considered a solution of the problem of overcoming the above scientific and technical barriers. This diagram should include a nonreciprocal element to ensure independence of measurement errors from the BO impedance.

Creation of a miniature radiometer will enable efficient, non-invasive MWR with acceptable accuracy during a long time. In the future, this circuit can be implemented in a monolithic design.

This work is devoted to the principles of designing a miniature radiometer based on analysis of design of a single-channel device. This is the first step towards creation of a multi-channel multifrequency radiometer in a monolithic design.

\section{The aim and objectives of the study}

The study objective is to analyze the proposed block diagram of a miniature radiometer that ensures stable operation of this device with acceptable measurement errors.

To achieve the objective, the following tasks were set:

- assess effect of self-temperature of the radiometer on errors occurring in measurement of temperature of internal tissues;

- assess effect of the feedback loop on errors in measuring temperature of internal tissues;

- verify experimentally correctness of choice of the proposed technical solutions.

\section{Description of the block diagram of the miniature microwave radiometer}

A microwave radiometer measures power of the noise signal coming from the antenna output. Block diagram of the miniature microwave radiometer proposed by the authors of this paper is presented in Fig. 1. Noise signal from a BO with temperature $T_{a}$ comes to the first input of SPDT switch. Noise signal from a reference noise source with temperature $T_{r}$ comes to the second input of the SPDT switch. The SPDT switch transmits the noise signal either from antenna or from the reference noise source (switching frequency is $1 \mathrm{kHz}$ ) to the circulator input and then to the low-noise amplifier. After amplification and amplitude detection, the noise signal comes to a synchronous detector. A voltage proportional to the difference of noise signals coming from the antenna and the reference source of noise signals is formed at the output of the synchronous detector (1):

$$
\Delta U=k\left(T_{a}-T_{r}\right) .
$$

It follows from (1) that if the noise temperature $T_{r}$ of the reference source is equal to the noise temperature $T_{a}$, then voltage at the output of the synchronous detector is zero:

$$
T_{a}=T_{r} \text {, if } \Delta U=0 \text {. }
$$

In the proposed miniature radio thermometer circuit, the reference noise source is implemented in a form of a matched RF load mounted on the Peltier element (Microwave load 1 in Fig. 1). The reverse side of the Peltier element is mounted on the metal base of the device. Temperature of the Peltier element and, accordingly, temperature of the RF load installed on it vary depending on polarity of the voltage supplied to the Peltier element. Thus, it is possible to heat up or cool the RF load by changing the voltage supplied to the Peltier ele- 
ment and, therefore, control the noise temperature of the reference source. Synchronous detector is implemented in the proposed miniature radiometer circuit as a field programmable analog array (FPAA). The reference voltage generator (RVG) which controls the SPDT switch and sends a control signal to the synchronous detector, the selective amplifier with the band-pass filter, the amplitude limiter and the delay line is implemented on the same microcircuit. At a large gain of the negative feedback loop, noise temperature $T_{r}$ of the heated resistor approaches temperature $T_{a}$ of the noise signal coming from the antenna output. If the heated resistor is matched to the microwave path, then its thermodynamic temperature coincides with its noise temperature, so the problem of measuring microwave power is reduced to a problem of measuring the thermodynamic temperature of the matched RF load. This can be done using a standard temperature sensor. The proposed radiometer scheme is quite simple, however, its implementation requires solution of several problems. The antenna is not always perfectly matched to the BO, thus the measured power at the antenna output differs from the power of the noise signal emitted by the BO. In the presence of dissipative losses in the input section of the radiometer, the noise signal at the switch output is not equal to the noise signal coming from the antenna output but depends on temperature $\mathrm{T}_{\text {rdamb }}$ of the input section of the radiometer. It will be described below how these problems are solved and how the radiometer error is minimized.

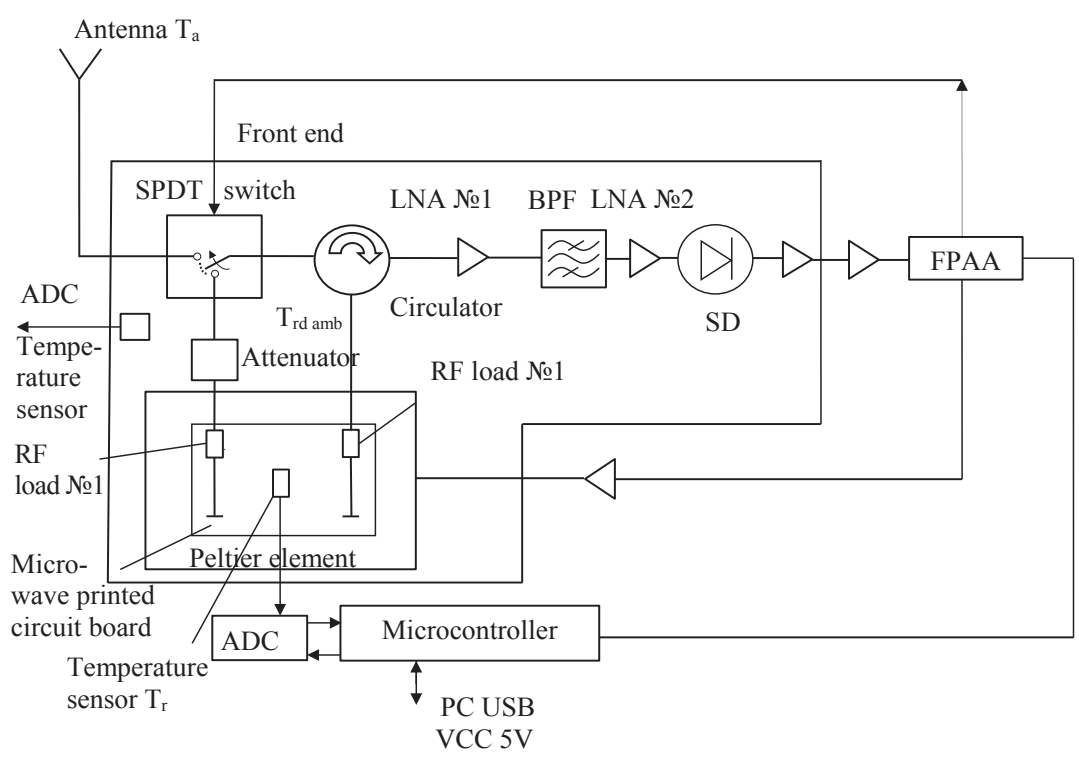

Fig. 1. Block diagram of the miniature microwave radiometer: low-noise amplifier (LNA), band-pass filter (BPF), synchronous detector (SD)

Obviously, the noise signal $T_{a 1}$ at the antenna output is smaller than the noise signal from the BO because of reflection of the noise signal from the antenna input and because of dissipative losses. At the first stage, let us assume that dissipative losses are negligible. In this case, the noise signal at the antenna output is determined from the following equation:

$$
T_{a 1}=T_{a}-T_{a}^{*} R^{2},
$$

where $R$ is the module of the antenna reflection coefficient; $T_{a 1}$ is the antenna noise temperature; $T_{a}$ is the $\mathrm{BO}$ noise temperature.

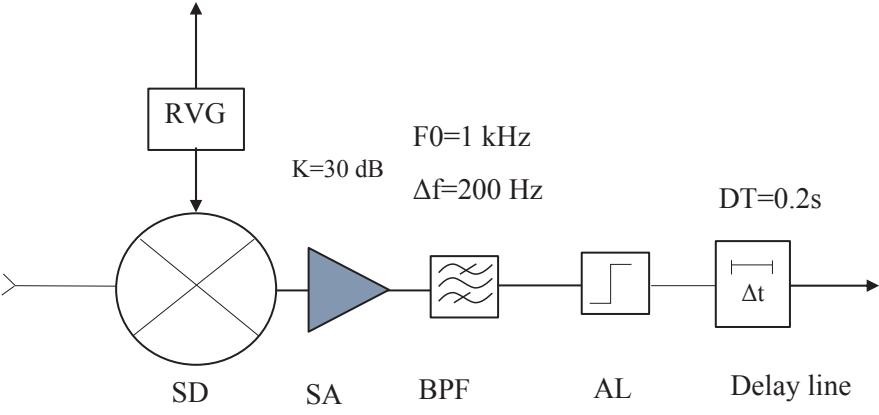

Fig. 2. The FPAA structure: synchronous detector (SD), selective amplifier (SA); band-pass filter (BPF); amplitude limiter (AL)

It should be borne in mind that dielectric permeability of biological tissues can vary over a wide range (from 6 to 50). Therefore, if antenna is matched to one patient, then it will have significant reflections for the other patient $\left(R^{2}\right.$ can reach 0.25 ). This will reduce level of the noise signal fed to the input of the low-noise amplifier and error in measuring the brightness temperature of tissues will increase. Therefore, one of the main problems in designing radiometers consists in reducing the device error when the antenna reflectance changes. This problem is solved in the proposed scheme by using a circulator and two RF loads installed on the Peltier element on a common heat-conducting base so that their temperatures are the same and equal to $T_{r}$. The circulator is included in the scheme in such a way that the signal from the RF load of the circulator with noise temperature $T_{r}$ enters input of the antenna and is partially reflected from it. Therefore, the noise signal coming to the input of the SPDT switch is determined from equation (4):

$$
T_{i n}=T_{a}-T_{a} \cdot R^{2}+T_{a r} \cdot R^{2}
$$

where $T_{\text {in }}$ is the noise signal at the switch output; $T_{a r}$ is the noise temperature of the signal entering the antenna input from the circulator RF load.

It follows from equation (4) that if $T_{a}=T_{a r}$

$$
T_{\text {in }}=T_{a} .
$$

That is, the antenna reflections are compensated and a signal with the BO noise temperature comes to the input of the receiving device. However, value of temperature $T_{a}$ is unknown, hence the problem of compensating for reflections from the antenna input is rather complicated in the general case. In order to bring temperature $T_{a r}$ closer to $T_{a}$ and reduce the measurement error, the circulator RF load is installed in the proposed miniature radiometer circuit on the same Peltier element base on which the RF load 1 is installed. Since temperature of the microwave load 1 is $T_{a}$ (excluding dissipative losses), the circulator RF load temperature will be equal to $T_{a}$ as well. Thus, compensation is provided for the measurement error associated with the antenna mismatch. In real circuits, the switch and the circulator have dissipative losses. This causes difference between the temperature $T_{a r}$ of the noise signal that enters the antenna input from the 
side of the circulator RF load and the temperature of the circulator RF load $T_{r}$ and $T_{a}$. Therefore, full reflection compensation does not occur in accordance with equation (4). If the circulator and the switch are installed on a common base, then it can be assumed that their temperatures are close and equal to $T_{\text {rdamb. }}$

In accordance with Sigman's theorem [36], the noise signal entering the antenna input from the side of the circulator $\mathrm{RF}$ load ( $\mathrm{RF}$ load 2) is described by equation (6)

$$
\begin{aligned}
& T_{a r}=T_{r} *\left(1-\alpha_{f}\right)+\alpha_{f} * T_{r d a m b}, \\
& \alpha_{f}=\alpha_{c i r}+\alpha_{s w}+\alpha_{a}, \\
& \alpha_{s w}=1-K_{s w}^{2}, \\
& \alpha_{c i r}=1-K_{c i r}^{2},
\end{aligned}
$$

where $\alpha_{c i r}$ is the loss on the circulator; $\alpha_{s w}$ is the loss on the switch; $\alpha_{a}$ is the loss on the input section of the radiometer; $T_{\text {rdamb }}$ is the temperature of the radiometer base on which the circulator and the switch are mounted; $K_{s w}$ is the module of the switch transmission coefficient; $K_{c i r}$ is the module of the circulator transmission coefficient.

Obviously, $T_{\text {rdamb }} \neq T_{r}$, therefore $T_{a r} \neq T_{a}$ and complete compensation of reflections does not occur. This leads to an increase in the measurement error associated with the antenna mismatch. To reduce this error, it was proposed to install an additional attenuator between the heated resistor and the SPDT switch which has temperature $T_{r d a m b}$. In this case, a signal with noise temperature $T_{r 2}$ enters the second input of the switch from the side of the reference voltage generator:

$$
T_{r 2}=T_{r} *\left(1-\alpha_{a t t}\right)+\alpha_{a t t} * T_{r d a m b},
$$

where $\alpha_{\text {att }}$ is the attenuator loss.

The condition of zero balance (2) is satisfied if

$$
T_{r 2}=T_{i n}
$$

It follows from (6) to (8) that if $\alpha_{a t t}=\alpha_{f}$, the measured brightness temperature does not depend on the antenna reflection coefficient and is determined by the resistor temperature and the temperature of the input section of the radiometer:

$$
T_{a}=T_{r} *\left(1-\alpha_{f}\right)+\alpha_{f} * T_{r d a m b}
$$

if $\alpha_{a t t}=\alpha_{f}$.

Thus, introduction of an additional attenuator with temperature $\mathrm{T}_{\text {rdamb }}$ in the reference signal circuit allows one to compensate for the signal reflected from the antenna and reduce the measurement error associated with the antenna mismatch.

The second important problem in development of a microwave radiometer consists in the fact that a noise signal comes at the input of a low-noise amplifier not only from the BO but also from all noisy elements of the input section of the radiometer. This is caused by the presence of dissipative losses in the circuit elements. Therefore, in the general case, when temperature of the input section of the radiometer changes, the measured brightness temperature changes. In some devices, in order to reduce this error, they try to thermally stabilize the radiometer. However, this significantly increases energy consumption by the device. Therefore, another option is proposed in this circuit to reduce the measurement error. If we assume that the switch is well matched and well uncoupled, then the noise temperature at the switch output is determined from equation (9):

$$
\begin{aligned}
& T_{a 1}=T_{a} *\left(1-\alpha_{w}\right)+\alpha_{w} * T_{r d a m b}, \\
& \alpha_{w}=\alpha_{s w}+\alpha_{a} .
\end{aligned}
$$

The noise signal from the heated resistor at the switch output is determined from the following equation:

$$
\begin{aligned}
& T_{p 1}=T_{r} *\left(1-\alpha_{p}\right)+\alpha_{p} * T_{r d a m b}, \\
& \alpha_{p}=\alpha_{s w}+\alpha_{\text {att }} .
\end{aligned}
$$

In order to make voltage at the output of the synchronous detector equal to zero, it is necessary that

$$
T_{p 1}=T_{a 1},
$$

where the following is obtained from (11) to (13):

$$
\begin{aligned}
& T_{r}=\frac{T_{a}}{A}+S^{*} T_{r d a m b}, \\
& T_{a}=A^{*} T_{r}+(1-A) * T_{r d a m b}, \\
& A=\frac{\left(1-\alpha_{p}\right)}{\left(1-\alpha_{w}\right)} \\
& S=1-\frac{1}{A} .
\end{aligned}
$$

It follows from (15) that temperature of the heated resistor $T_{r}$ is not equal to $T_{a}$ and depends on temperature $T_{r d a m b}$ of the input section of the radiometer. This leads to an increase in the error of temperature measurement when temperature $T_{\text {rdamb }}$.changes. In this work, instead of stabilizing temperature $T_{\text {rdamb }}$, it is proposed to compensate for its influence on the measurement results. To compensate for this error, it is necessary to measure temperature $\mathrm{T}_{r d a m b}$ and calculate the measured temperature using formula (18):

$$
T_{\text {изм }}=H^{*} T_{r}-k T_{\text {rdamb }}+b .
$$

It follows from (15) to (18) that if $H=A$ and $k=S^{*} H$, then

$$
\mathrm{T}_{\text {measured }}=\mathrm{T}_{a} \text {. }
$$

Thus, the measured temperature is independent of $T_{\text {rdamb }}$.

To find the coefficient $S$, it is necessary to heat up the radiometer and measure slope of the curve in equation (15) when calibrating the instrument at a fixed value of $T_{a}$. To find the coefficient $H$ during the calibration process, it is necessary to apply a fixed value of the noise temperature $T_{a 1}$ to the radiometer input and measure temperature of the heated resistor, $T_{r 1}$, with the feedback loop closed. Then temperature $T_{a 2}$ is applied to the input and $T_{r 2}$ is measured. If temperature $T_{\text {rdamb }}$ of the inlet section of the radiometer does not change during measurement, then the calibration factor is determined from the following formula: 


$$
\begin{aligned}
& H=\frac{T_{a 2}-T_{a 1}}{T_{r 2}-T_{r 1}}, \\
& b 0=T_{r 1}-\frac{T_{a 1}}{H}-S^{*} T_{r d a m b} * T_{a} .
\end{aligned}
$$

Signal is processed in the microwave radiometer [19] after its detection in the data processing unit. In the considered circuit of the miniature radiometer, this function is implemented in the FPAA which can have static and dynamic structure configurations. In statically programmable circuits, configuration data are loaded when FPAA is turned on and remains unchanged during its operation. When the supply voltage is sent to the chip, the FPAA configuration memory is cleared and the configuration logic automatically downloads data from the EPROM. After the data download is complete, the FPAA automatically activates the analog structure. The dynamically configurable circuit makes it possible to change fully or partially the functional structure in real time. Configuration interfaces of the devices with dynamic configuration contain special functions that enable loading of reconfiguration data on the fly, without having to reboot the device. In the considered option of the design of the miniature radiometer, the FPAA has a statically configurable structure. In this case, the amplifier feedback gain and the pass band, as well as all other parameters of the circuit remained constant during the measurement process and changed only during debugging of the circuit. When the FPAA circuit is dynamically configured, there is a possibility to dynamically change gain of the feedback loop, frequency band of the selective amplifier and the time constant of the delay line. The ability to quickly reconfigure all parameters of the receiving device allows one to optimize the transient process and thereby reduce the measurement time, thereby increasing the device speed. The use of the FPAA microcircuit for signal processing makes it possible to mount entire elements of the radiometer in a volume of $9 \mathrm{~cm}^{3}$ which is more than 100 times smaller than the existing serial device.

\section{The effect of feedback on parameters of the radiometer}

When analyzing the radiometer circuit, it was assumed that voltage at the output of the synchronous detector is zero and the noise signal from the reference noise source is equal to the noise signal that comes from the BO. However, gain of the feedback loop is finite in a real device, so there is a residual voltage at the output of the synchronous detector any time. This voltage is applied to the Peltier element and the temperature $T_{r}$ of the RF load differs from $T_{a}$.

If voltage $\Delta U_{p}$ is applied to the Peltier element, then temperature of the RF load installed on it will increase by $\Delta T_{r}$. In this case, slope of the characteristic will be determined as follows:

$$
k_{r}=\frac{\Delta T_{r}}{\Delta U_{p}} .
$$

When the noise signal at the first input of the switch increases by $\Delta T_{a}$, voltage at the input of the Peltier element increases by $\Delta U p$ when the feedback loop is open. Then, gain of this section of the feedback loop will be

$$
k_{p}=\frac{\Delta U_{p}}{\Delta T_{a}} .
$$

Based on definitions (22) and (23), we can write equations for voltage at the output of the amplifier connected to the Peltier element when the feedback loop is closed:

$$
\begin{aligned}
& \Delta U_{p}=k_{p}\left(T_{r 1}-T_{r 2}\right) . \\
& T_{r 2}=k_{r}{ }^{*} \Delta U_{p}+T_{r d a m b}, \\
& T_{r}=\frac{T_{a}}{A f}+S^{*} T_{r d a m b}, \\
& A f=\frac{\left(1-\left(\alpha_{s w}+\alpha_{a t t}\right)+\frac{1}{F}\right)}{\left(1-\left(\alpha_{a}+\alpha_{s w}\right)\right)}, \\
& S=1-\frac{1}{A f}, \\
& F=k_{r}^{*} k_{p} .
\end{aligned}
$$

It follows from equations (27) to (29) that the coefficient of gain of the feedback loop affects the measured temperature and the calibration coefficients. However, if this coefficient is greater than 10 , then this influence is not very significant. It should also be borne in mind that this gain also determines speed of the device. The RF load time constant is about $3 \mathrm{~s}$. At the same time, an $F$-fold decrease in the time constant occurs and it becomes less than one second when the feedback loop is closed.

A computer program that implemented the described algorithm of calculation of the measured temperature makes it possible to visualize the results of measuring the brightness temperature. The program visualizes temperature $T_{r}$ of the matched RF load as a function of time, the measured temperature $T_{\text {measured }}$ of the $\mathrm{BO}$ calculated according to formula (18) and temperature $\mathrm{T}_{\text {rdamb }}$ of the housing. Obviously, to reduce the fluctuation error, it is necessary to average the measurement results over a certain time. The program displays the results of measurement of both averaged and "raw" temperature data coming from temperature sensors. In addition, the program enables a quick change of the averaging time and observation of a decrease in the fluctuation error. In addition, the program also helps to calibrate the device by calculating the calibration coefficients $H$ and $b$ and the coefficient $k$ of thermal stability in equation (18). The results of prototyping the proposed scheme of the miniature radiometer are given below.

\section{Experimental verification of correctness of choice of technical solutions}

Experimental studies of the radiometer circuit were conducted. In these studies, the range of temperature measurements was chosen within $32-42^{\circ} \mathrm{C}$ and the ambient temperature ranged from $18{ }^{\circ} \mathrm{C}$ to $35^{\circ} \mathrm{C}$.

A noise generator was used in calibration as a noise source in which a matched RF load heated up to a fixed adjustable temperature was used as a noise signal source. Temperature of the matched RF load can be set with an 
accuracy of $0.01{ }^{\circ} \mathrm{C}$. To measure the amplitude-frequency characteristic of the microwave path, an amplitude-modulated microwave signal from the standard signal generator was applied to the device input. Power of the input signal was adjusted so that the envelope voltage at the output of the amplifier switched on after the detector was maintained at $200 \mathrm{mV}$. The input signal level was $-115 \mathrm{~dB} / \mathrm{W}$ at a central frequency. The amplitude-frequency characteristic of the microwave path is presented in Fig. 3. Gain at the central frequency was $45 \mathrm{~dB}$. The noise band was calculated using the following formula:

$$
\Delta F(\mathrm{MHz})=\sum_{i=1}^{n} k_{i}^{*} h,
$$

where $h$ is the magnitude of the frequency step, $\mathrm{MHz} ; k_{i}$ is the power-normalized coefficient of transmission at frequency $i$.

The noise band was approximately equal to the pass band of the path at the level of $3 \mathrm{~dB}$ and amounted to $720 \mathrm{MHz}$.

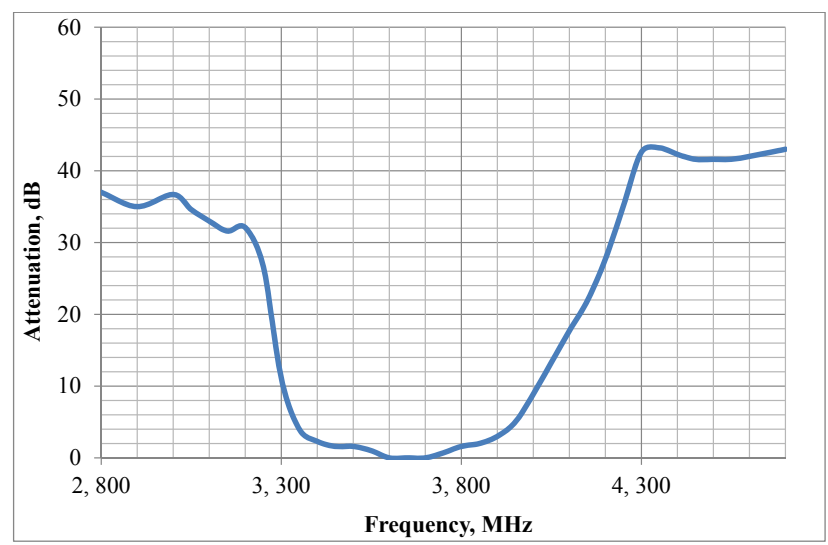

Fig. 3. Amplitude-frequency characteristic of the microwave path

To study the transient process, a noise signal from the noise generator was applied to the input of the radiometer circuit at temperature of $32{ }^{\circ} \mathrm{C}$. At a certain point in time, the noise generator was switched to a temperature of $38^{\circ} \mathrm{C}$. Fig. 4 shows a transient process of the miniature radiometer.

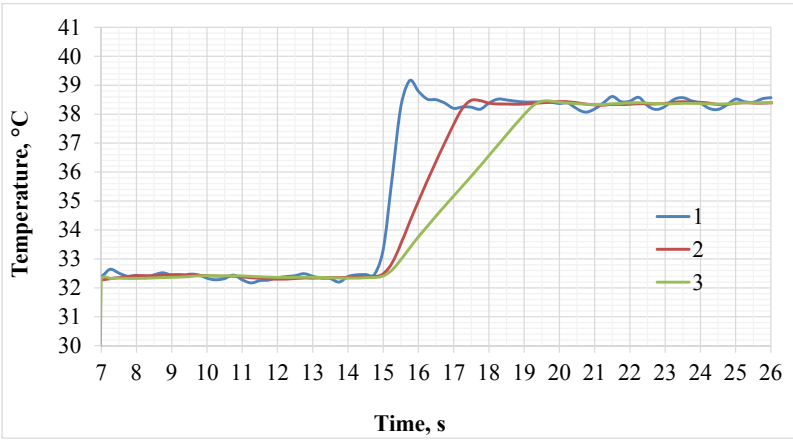

Fig. 4. Transient process of the miniature radiometer: temperature $T_{r}$ of the heated resistor without additional averaging (curve 1) (1); $T_{r}$ with a $2 \mathrm{sec}$ averaging (curve 2) (2); $T_{r}$ with a 4 sec averaging (curve 3 ) (3)

Fig. 5 shows the measured temperature (curve 3) calculated by formula (18) and averaged within 4 seconds, the non-averaged temperature (curve 1) of the heated resistor $\left(T_{r}\right)$ and temperature of the input section of the radiometer
( $\left.T_{r d a m b}\right)$ (curve 2). Heating was executed through heat release from elements of the radiometer. A normalized noise signal with temperature of $32{ }^{\circ} \mathrm{C}$ entered the radiometer input and then a noise signal with a temperature of $38^{\circ} \mathrm{C}$ was received after $12 \mathrm{~min}$.

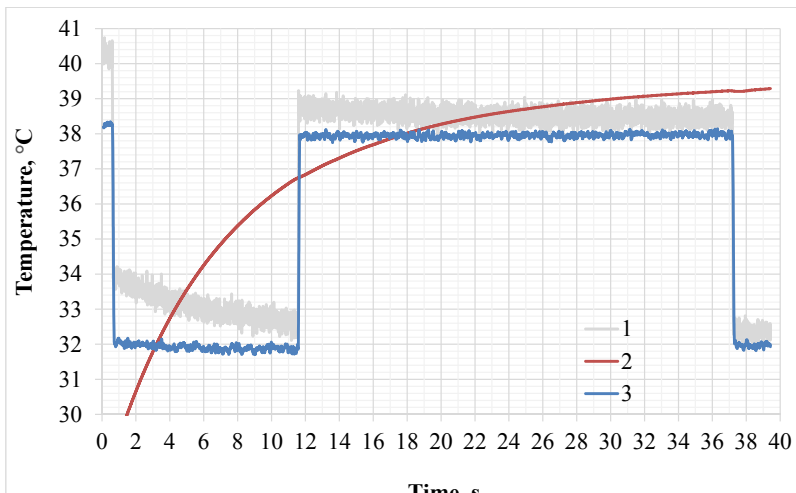

Time, $\mathbf{s}$

Fig. 5. Dependence of the measured temperature on time: not averaged temperature of the heated resistor (1); temperature of the inlet section of the radiometer, $\left(T_{\text {rdamb }}\right)(2)$; measured temperature averaged within $4 \mathrm{~s}(3)$

To assess effect of antenna mismatch on the measurement results, a mismatch element with $\left|S_{1,1}\right|^{2}=0,25$, was installed between the noise generator and the input of the miniature radiometer. It was a piece of coaxial cable with air filling. Diameter of the central conductor was selected so that $\left|S_{1,1}\right|^{2}$ was close to 0.25 .

Table 1 shows the results of temperature measurement with and without mismatch. A noise signal with temperature of $32^{\circ} \mathrm{C}$ and $38^{\circ} \mathrm{C}$ was fed from the generator to the input of the miniature radiometer. It is obvious that the radiometer had an acceptable measurement error.

Table 1

Results of temperature measurement with and without the mismatch element

\begin{tabular}{|c|c|c|c|}
\hline $\begin{array}{c}\text { Tempera- } \\
\text { ture of the } \\
\text { noise gener- } \\
\text { ator, }{ }^{\circ} \mathrm{C}\end{array}$ & $\begin{array}{c}\text { Temperature } \\
\text { measured without } \\
\text { the mismatch } \\
\text { element, }{ }^{\circ} \mathrm{C}\end{array}$ & $\begin{array}{c}\text { Temperature } \\
\text { measured with } \\
\text { the mismatch } \\
\text { element, }{ }^{\circ} \mathrm{C}\end{array}$ & $\begin{array}{c}\text { Error of } \\
\text { temperature } \\
\text { measurement, } \\
{ }^{\circ} \mathrm{C}\end{array}$ \\
\hline 32 & 32 & 31.8 & -0.2 \\
\hline 38 & 38 & 37.85 & -0.15 \\
\hline
\end{tabular}

\section{Discussion of the results obtained from experimental studies of the miniature radiometer circuit}

The noise band of the path in the proposed miniature radiometer circuit was $720 \mathrm{MHz}$. This band is primarily determined by the filter band. In this variant of design of the radiometer, a miniature band-pass filter having size of $4 \times 4 \times 0,5 \mathrm{~mm}$ with attenuation bands at finite frequencies was used. The band-pass filter was a 4-link filter with additional coupling [37] implemented on a substrate with high dielectric permeability $(\varepsilon=100)$. It is noted in many articles that radiometer for which a matched load is used as a noise source have a low speed because the matched load has a large time constant. Indeed, the used RF load which had dimensions of $0.32 \times 0.4 \mathrm{~mm}$ had time constant of $3.2 \mathrm{~s}$. 
However, due to the negative feedback, the frequency band expands and speed improves. It is seen from Fig. 4 showing the transient process of the radiometer circuit that the transient time was less than $1 \mathrm{sec}$. despite the fact that the time constant of the resistor was $3.2 \mathrm{sec}$. With this design of the device, gain of the open feedback loop was chosen equal to 4.12. An additional gain increase is very easy to implement in FPAA. To do this, it would suffice to change its firmware. It must be borne in mind that this action increases energy consumed by the device and raises temperature of the radiometer in working conditions. In many problems, slow thermal changes occur in the BO tissues, therefore speed of 0.5-2 s may be acceptable for such applications. When monitoring the BO internal (or brightness) temperature, it is important to ensure stability of measurements and independence of the measurement results from the ambient temperature and the own temperature of the radiometer. The experiment presented in Fig. 5 shows that despite the fact that the base of the radiometer was heated up by $10{ }^{\circ} \mathrm{C}$, the measured temperature calculated from formula (18) with allowance for thermal compensation has changed by only $0.1{ }^{\circ} \mathrm{C}$ while without thermal compensation, temperature of the heated microwave load changed by $1.4{ }^{\circ} \mathrm{C}$. Thus, this experiment clearly shows that introduction of thermal compensation can significantly improve accuracy of measurements. The experiment has confirmed that the proposed scheme of reflection compensation provides a significant reduction of measurement error even at a significant antenna mismatch. This makes it possible to ensure stable operation of the miniature radiometer when the BO impedance changes. Use of the proposed scheme for designing radiometers makes it possible to obtain a more than 100 times reduction of weight and size parameters in comparison with a stationary device. Therefore, this scheme can be applied to design miniature radiometers.

This study did not address the issues of design implementation of a miniature radiometer. This will be done at the next stage of studies. Also, issues of designing miniature antennas for the proposed device will be considered at the next stage. In particular, issues of designing textile antennas that have a low cost and provide good contact with the patient's body will be considered. It is also planned to develop a wireless interface and software for working with a phone or a tablet. Creation of a miniature radiometer opens up the possibility of creating various wearable devices and a family of multi-channel radiometers: Smart Bra, Smart Carotid, Smart Helmet which can be used in telemedicine. Currently, artificial intelligence systems are developing rapidly. They help interpret results of measurements of tissue self-radiation in the microwave range [38]. Their introduction into medical practice in combination with miniaturization of equipment will make it possible to bring microwave radiometry to a qualitatively new level.

\section{Conclusions}

1. Analysis of the radiometer circuit has shown that the measured temperature depends on temperature of the front end of the radiometer because of dissipative losses in front end of the radiometer. Change of the input section temperature by $20{ }^{\circ} \mathrm{C}$ leads to a change of the measured temperature by $2{ }^{\circ} \mathrm{C}$. Application of the thermal compensation algorithm makes it possible to reduce the measurement error to $0.2^{\circ} \mathrm{C}$.

2. An analytical relationship between the measured temperature and the coefficient of transmission of the feedback loop has been established. It was established that the coefficient of transmission of an open feedback loop affects basic parameters of the radiometer: speed, fluctuation error, thermal stability, etc. If the coefficient of transmission exceeds 10, its effect decreases.

3. Experimental studies of the circuit of the miniature radiometer operating in the frequency range of 3,400$4,100 \mathrm{MHz}$ have shown that introduction of thermal compensation reduces measurement errors associated with device heating to $0,2{ }^{\circ} \mathrm{C}$ when the radiometer temperature is $20{ }^{\circ} \mathrm{C}$. Introduction of a mismatch element at the input of the device with a reflection coefficient $\left|S_{1,1}\right|^{2}=0,25$ leads to a measurement error of $0,2{ }^{\circ} \mathrm{C}$.

\section{Acknowledgment}

The research was carried out with the support of Russian science Foundation (project No. 19-19-00349).

\section{References}

1. Vesnin, S., Turnbull, A. K., Dixon, J. M., Goryanin, I. (2017). Modern Microwave Thermometry for Breast Cancer. Journal of Molecular Imaging \& Dynamics, 7 (2). doi: https://doi.org/10.4172/2155-9937.1000136

2. Sedankin, M. K., Leushin V. Yu., Gudkov, A. G., Vesnin, S. G., Sidorov, I. A., Agasieva, S. V., Markin, A. V. (2018). Mathematical Simulation of Heat Transfer Processes in a Breast with a Malignant Tumor. Biomedical Engineering, 52 (3), 190-194. doi: https:// doi.org/10.1007/s10527-018-9811-2

3. Cheboksarov, D. V., Butrov, A, V., Shevelev, O. A., Amcheslavsky, V. G., Pulina, N. N., Buntina, M. A., Sokolov, I. M. (2015). Diagnostic opportunities of noninvasive brain thermomonitoring. Anesteziologiia i reanimatologiia, 60 (1), 66-69.

4. Toutouzas, K., Benetos, G., Koutagiar, I., Barampoutis, N., Mitropoulou, F., Davlouros, P. et. al. (2017). Noninvasive detection of increased carotid artery temperature in patients with coronary artery disease predicts major cardiovascular events at one year: Results from a prospective multicenter study. Atherosclerosis, 262, 25-30. doi: https://doi.org/10.1016/j.atherosclerosis.2017.04.019

5. Drakopoulou, M., Moldovan, C., Toutouzas, K., Tousoulis, D. (2018). The role of microwave radiometry in carotid artery disease. Diagnostic and clinical prospective. Current Opinion in Pharmacology, 39, 99-104. doi: https://doi.org/10.1016/j.coph.2018.02.008

6. Zampeli, E., Raftakis, I., Michelongona, A., Nikolaou, C., Elezoglou, A., Toutouzas, K. et. al. (2013). Detection of Subclinical Synovial Inflammation by Microwave Radiometry. PLoS ONE, 8 (5), e64606. doi: https://doi.org/10.1371/journal.pone.0064606 
7. Crandall, J. P., O, J. H., Gajwani, P., Leal, J. P., Mawhinney, D. D., Sterzer, F., Wahl, R. L. (2018). Measurement of Brown Adipose Tissue Activity Using Microwave Radiometry and18F-FDG PET/CT. Journal of Nuclear Medicine, 59 (8), $1243-1248$. doi: https://doi.org/10.2967/jnumed.117.204339

8. Kublanov, V. S., Borisov, V. I. (2017). Biophysical Evaluation of Microwave Radiation for Functional Research of the Human Brain IFMBE Proceedings, 1045-1048. doi: https://doi.org/10.1007/978-981-10-5122-7_261

9. Groumpas, E., Koutsoupidou, M., Karanasiou, I., Papageorgiou, C., Uzunoglu, N. (2019). Real-time Passive Brain Monitoring System Using Near-Field Microwave Radiometry. IEEE Transactions on Biomedical Engineering.

10. Tarakanov, A. V., Efremov, V. V., Tarakanov, A. A. (2016). Perspectives of microwave radiometry application at dorsopathy in hospital department of the emergency medical care. Emergency medical care, 1, 64-68.

11. Ravi, V. M., Sharma, A. K., Arunachalam, K. (2019). Pre Clinical Testing of Microwave Radiometer and a Pilot Study on the Screening Inflammation of Knee Joints. Bioelectromagnetics, 40 (6), 402-411. doi: https://doi.org/10.1002/bem.22203

12. Zamechnik, T. V., Larin, S. I., Losev, A. G. (2015). Kombinirovannaya radiotermometriya kak metod issledovaniya venoznogo krovoobrashcheniya nizhnikh konechnostey [Combined Radio Thermometry as a Method of Investigating of Venous Circulation of the Lower Limbs]. Volgograd: Izd-vo VolgGMU, 252.

13. Zinovyev, S. V. (2018). New Medical Technology - Functional Microwave Thermography: Experimental Study. KnE Energy, 3 (2), 547. doi: https://doi.org/10.18502/ken.v3i2.1864

14. Khashukoeva, A. Z., Tsomaeva, E. A., Vodianyk, N. D. (2012). Zastosuvannia transabdomynalnoi i vahinalnoi radiotermometriyi v kompleksniy diahnostytsi zapalnykh zakhvoriuvan prydatkiv matky. Likuvannia ta profilaktyka, 1, 26-30.

15. Kaprin, A. D., Kostin, A. A., Andryukhin, M. I., Ivanenko, K. V., Popov, S. V., Shegai, P. V. et. al. (2019). Microwave Radiometry in the Diagnosis of Various Urological Diseases. Biomedical Engineering, 53 (2), 87-91. doi: https://doi.org/10.1007/s10527-019-09883-3

16. Snow, B. W., Arunachalam, K., De Luca, V., Maccarini, P. F., Klemetsen, ., Birkelund, Y. et. al. (2011). Non-invasive vesicoureteral reflux detection: Heating risk studies for a new device. Journal of Pediatric Urology, 7 (6), 624-630. doi: https://doi.org/10.1016/ j.jpurol.2011.05.005

17. Ivanov, Y., Kozlov, A. F., Galiullin, R. A., Tatur, V. Y., Ziborov, V. S., Ivanova, N. D. et. al. (2018). Use of Microwave Radiometry to Monitor Thermal Denaturation of Albumin. Frontiers in Physiology, 9. doi: https://doi.org/10.3389/fphys.2018.00956

18. Ivanov, Y. D., Kozlov, A. F., Malsagova, K. A., Pleshakova, T. O., Vesnin, S. G., Tatur, V. Y. et. al. (2016). Monitoring of microwave emission of HRP system during the enzyme functioning. Biochemistry and Biophysics Reports, 7, 20-25. doi: https://doi.org/ 10.1016/j.bbrep.2016.05.003

19. Toutouzas, K., Synetos, A., Nikolaou, C., Stathogiannis, K., Tsiamis, E., Stefanadis, C. (2012). Microwave radiometry: a new non-invasive method for the detection of vulnerable plaque. Cardiovascular diagnosis and therapy, 2 (4), 290-297. doi: http:// doi.org/10.3978/j.issn.2223-3652.2012.10.09

20. Tikhomirov, V. G., Gudkov, A. G., Agasieva, S. V., Gorlacheva, E. N., Shashurin, V. D., Zybin, A. A. et. al. (2017). The sensitivity research of multiparameter biosensors based on HEMT by the mathematic modeling method. Journal of Physics: Conference Series, 917, 042016. doi: https://doi.org/10.1088/1742-6596/917/4/042016

21. Parnes, Y. M., Tikhomirov, V. G., Petrov, V. A., Gudkov, A. G., Marzhanovskiy, I. N., Kukhareva, E. S. et. al. (2016). Evaluation of the influence mode on the CVC GaN HEMT using numerical modeling. Journal of Physics: Conference Series, 741, 012024. doi: https:// doi.org/10.1088/1742-6596/741/1/012024

22. Gudkov, A.G., Tikhomirov, V.G., Agasieva, S.V. et. al.(2017). Dependence analysis of the GaN HEMT parameters for space application on the thickness AlGaN barrier layer by numerical simulation. 2017 IEEE 2nd International Conference on Opto-Electronic Information Processing (ICOIP). doi: https://doi.org/10.1109/optip.2017.8030703

23. Gudkov, A.G.,Tikhomirov, V. G., Petrov, V.A, Agasieva, S.V., Zybin, A.A. et. al. (2017). Simulation of electric field distribution in GaN HEMTs for the onset of structure degradation. 2017 11th International Workshop on the Electromagnetic Compatibility of Integrated Circuits (EMCCompo). doi: https://doi.org/10.1109/emccompo.2017.7998094

24. Gudkov, A. G., Ivanov, Y. A., Meshkov, S. A., Agasieva, S. V., Petrov, V. I., Sinyakin, V. Y., Schukin, S. I. (2015). Prospects for Application of Radio-Frequency Identification Technology with Passive Tags in Invasive Biosensor Systems. Biomedical Engineering, 49 (2), 98-101. doi: https://doi.org/10.1007/s10527-015-9506-x

25. Gudkov, A. G. (2004). Optimal designing of microstrip discrete phase-stable attenuator with allowance for production technology. Radiotekhnika, 2, 67-72.

26. Vidyakin, S. I., Gudkov, A. G., Oganesyan, G. A., Petrov, V. N., Sakharov, A. V., Shabunina, E. I. et. al. (2016). Impact of nanomaterial arrangement on the reliability and the electron mobility in AlGaN/GaN HEMTs. Journal of Physics: Conference Series, 741, 012172. doi: https://doi.org/10.1088/1742-6596/741/1/012172

27. Emtsev, V. V., Zavarin, E. E., Oganesyan, G. A., Petrov, V. N., Sakharov, A. V., Shmidt, N. M. et. al. (2016). The relationship between the reliability of transistors with 2D AlGaN/GaN channel and organization type of nanomaterial. Technical Physics Letters, 42 (7), 701-703. doi: https://doi.org/10.1134/s1063785016070075 
28. Iudicello, S., Bardati, F. (2009). Microwave radiometry for breast cancer detection. Dottorato di ricerca in Geoinformazione, Universita'degli studi di Roma” Tor Vergata.

29. Stauffer, P. R., Rodriques, D. B., Salahi, S., Topsakal, E., Oliveira, T. R., Prakash, A. et. al. (2013). Stable microwave radiometry system for long term monitoring of deep tissue temperature. Energy-Based Treatment of Tissue and Assessment VII. doi: https:// doi.org/10.1117/12.2003976

30. Momenroodaki, P., Haines, W., Popovic, Z. (2017). Non-invasive microwave thermometry of multilayer human tissues. 2017 IEEE MTT-S International Microwave Symposium (IMS). doi: https://doi.org/10.1109/mwsym.2017.8058873

31. Momenroodaki, P., Haines, W., Fromandi, M., Popovic, Z. (2018). Noninvasive Internal Body Temperature Tracking With NearField Microwave Radiometry. IEEE Transactions on Microwave Theory and Techniques, 66 (5), 2535-2545. doi: https://doi.org/ 10.1109/tmtt.2017.2776952

32. Popovic, Z., Momenroodaki, P., Scheeler, R. (2014). Toward wearable wireless thermometers for internal body temperature measurements. IEEE Communications Magazine, 52 (10), 118-125. doi: https://doi.org/10.1109/mcom.2014.6917412

33. Ravi, V. M., Arunachalam, K. (2019). A low noise stable radiometer front-end for passive microwave tissue thermometry. Journal of Electromagnetic Waves and Applications, 33 (6), 743-758. doi: https://doi.org/10.1080/09205071.2019.1576063

34. Sedankin, M., Chupina, D., Vesnin, S., Nelin, I., Skuratov, V. (2018). Development of a miniature microwave radiothermograph for monitoring the internal brain temperature. Eastern-European Journal of Enterprise Technologies, 3 (5 (93)), 26-36. doi: https:// doi.org/10.15587/1729-4061.2018.134130

35. Livanos, N.-A., Hammal, S., Nikolopoulos, C. D., Baklezos, A. T., Capsalis, C. N., Koulouras, G. E. et. al. (2018). Design and Interdisciplinary Simulations of a Hand-Held Device for Internal-Body Temperature Sensing Using Microwave Radiometry. IEEE Sensors Journal, 18 (6), 2421-2433. doi: https://doi.org/10.1109/jsen.2018.2791443

36. Siegman, A. E., Hagger, H. J. (1964). Microwave Solid-state Masers. Physics Today, 17 (10), 65-66. doi: https://doi.org/ $10.1063 / 1.3051185$

37. Osipenkov, V., Vesnin, S. G. (1994). Microwave filters of parallel-cascade structure. IEEE Transactions on Microwave Theory and Techniques, 42 (7), 1360-1367. doi: https://doi.org/10.1109/22.299730

38. Galazis, C., Vesnin, S., Goryanin, I. (2019). Application of Artificial Intelligence in Microwave Radiometry (MWR). Proceedings of the 12th International Joint Conference on Biomedical Engineering Systems and Technologies. doi: https://doi.org/ $10.5220 / 0007567901120122$ 